\title{
O ensino apresentado por Ramon Llull por meio da simbologia da natureza
}

\section{The teaching used by Ramon Llull through symbology of nature}

\author{
Conceição Solange Bution PERIN ${ }^{1}$ \\ Terezinha OLIVEIRA²
}

\begin{abstract}
Resumo
Entender a simbologia usada no século XIII, por Ramon LLull (1232-1316), é compreender um pouco sobre as necessidades que os homens viviam e que os levavam a explorar a racionalidade. Logo, a nossa questáo é a de analisar a prioridade do conhecimento como questão central da formação humana. Pretendemos fazer uma reflexão sobre a obra de Llull para compreender sobre o papel de quem ensina e a importância da transformação do discurso na ação/prática.
\end{abstract}

Palavras-chave: Simbologia da natureza. Inteligência. Razão-fé. Ramon LLull.

\begin{abstract}
Understand the symbolism used in the thirteenth century, as an example, Ramon LLull (1232-1316), is to understand a little of the needs that the men lived and that led them to explore rationality. Our question is to analyse the priority of knowledge as a central issue of human formation. We want to reflect on Llull's work so that we can reflect on the role of those who teach and the importance of the transformation of discourse in action/practice.
\end{abstract}

Keywords: Symbology of nature. Intelligence. Reason-faith. Ramon LLull.

1 Doutora em Educação pelo Programa de Pós-Graduação em Educaçáo (PPE) da Universidade Estadual de Maringá - UEM. Professora Associada da Universidade Estadual do Paraná - Unespar/campus de Paranavaí. Lattes: http://lattes.cnpq.br/8838312470687058. Orcid: https://orcid.org/0000-0002-4033-270X. E-mail: solperin01@gmail.com

2 Doutora em História pela Universidade Estadual Paulista Júlio Mesquista (Unesp). Professora Titular da Universidade Estadual de Maringá - UEM. Bolsa Produtividade em Pesquisa do CNPq - nível 1C. Lattes: http://lattes.cnpq.br/7525108577501517. Orcid: https://orcid.org/0000-0001-5349-1059. E-mail: teleoliv.@gmail.com 
O objetivo desse estudo é analisar algumas questóes que perpassam o período estudado, o século XIII, e mantém-se como questóes fundamentais para a formação humana no século XXI. Elegemos como fonte para nossas reflexôes o autor Ramon LLull, particularmente a sua obra $O$ livro do Gentio e dos três Sábios escrita em 1274-1276.

Como esse autor foi um dos personagens mais importantes da Península Ibérica, no século XIII, antes de adentrarmos na análise da obra faremos uma breve apresentação da biografia do autor. Llull nasceu no ano de 1232, na ilha de Palma de Maiorca, local que "[...] possuía características culturais peculiares e que imprimiram um tom universal à obra de Ramon Llull. Existiam ali grupos de imigrantes de diversas partes da Europa, mulçumanos e judeus" (COSTA, 2006, p. 107). A convivência com as diferentes culturas, possibilitou com que Llull tivesse um diálogo com as religióes judaica e muçulmana.

Apesar da sua conversáo ao cristianismo ter sido por volta dos trinta anos, ele teve uma dedicação extrema a vida cristã "Vendeu então a maior parte de seus bens e deixou somente uma pequena parte para a sua esposa e filhos [...] abandonou sua vida de fausto e vestiu um hábito do mais vil trapo, "o mais rústico que pôde encontrar" (COSTA, 2006, p. 108). O fato de Llull ter escolhido a vida 'pobre' e o uso das roupas rústicas, segundo Costa, o fez ser considerado próximo do ideal da Ordem dos franciscanos.

A nosso ver, certamente, essa inclinação religiosa do autor é o que norteia as ideias contidas na obra que escolhemos para tratar sobre o projeto de formação da pessoa de Llull. O livro do Gentio e dos três Sábios pode ser considerado um 'manual' de ensinamento para a convivência dos homens do século XIII, pois o autor cria um debate entre um cristâo, um judeu e um muçulmano, fazendo com que os três sábios evidenciem a um gentio (representado por um personagem descrente da vida, pelo fato de saber que um dia vai morrer) como é possível saber que Deus existe e como acreditar que um dia ocorrerá a ressurreição. Partindo do pressuposto de que se Deus não é visível, não pode ser comprovado empiricamente.

Portanto, um grande problema está criado para o debate. Llull (personagem do gentio) não hesita em revelar aos três sábios que ele é descrente da existência de Deus e que os sábios deverão usar de todos os argumentos que conhecem para fazê-lo mudar de ideia. Pensando que estamos tratando mais especificamente do final do século XIII (1274-1276), quando a obra foi escrita, é difícil imaginar três religiosos, com pensamentos tão diferentes, quando analisados por meio da crença, para realizarem esse debate. $\mathrm{O}$ autor recorre a um ensinamento articulado para mostrar que os três homens podem ser considerados sábios, uma vez que, para o debate é 
necessário o uso da razão e da inteligência como instrumentos essenciais para uma discussão sobre as virtudes na formação humana. De acordo com o autor, essas virtudes são: o conhecimento, o respeito pelo pensamento alheio, o raciocínio lógico, a preocupação com o bem comum, a humildade, a boa convivência e entendimento sobre o uso da razáo e da fé.

Observamos, também, que a simbologia da natureza permeia toda a obra. O início retrata um lugar bonito, que inspira tranquilidade, e o autor descreve cinco árvores em círculo e uma linda mulher passeando a cavalo. O nome da mulher é Inteligência e ela explica aos três sábios o significado das flores das árvores.

\section{O ensino realizado pelo autor por meio da simbologia da árvore e dos números}

Os números, normalmente, estão presentes nos textos medievais relacionando a fé com a razão. Os autores que determinam a ciência como prioridade para o conhecimento divino, dentre eles Hugo de São Vitor (1096-1141), Boaventura de Bagnoregio (1221-1274), Nicole de Oresme (1320-1382), Nicolau de Cusa (1401-1464), veem os números como possibilidade de comprovação da criação de tudo e de todos, por Deus. Logo, o uso da matemática como ciência pode ser considerada uma das vias de conhecimento para entender a fé como supremacia de todas as demais ciências. O uso dos números, realizado implicitamente na obra, nos indica que o autor considera a matemática como uma ciência lógicodemonstrativa, ou seja, aquela que pode comprovar, por meio do raciocínio, a existência de Deus.

Llull, ao destacar a Inteligência e as cinco árvores, mostra aos sábios o significado de cada uma delas, exemplificando que, juntas, representam uma união da natureza com a sabedoria (fé e razáo), podendo ser comprovada, essa uniáo, por meio da correspondência que cada árvore traz pelas suas flores. As flores estabelecem os laços entre as virtudes e as açóes humanas com os ensinamentos divinos.

$\mathrm{Na}$ obra de Llull Arbol Ejemplifical, o autor apresenta a divisão que estabelece a explicação que será tratada no texto, portanto, as árvores, as quais citaremos da obra $O$ Livro do Gentio e dos Três Sábios, não se distanciam dos princípios tratados por Llull em outras obras nas quais ela é vista como símbolo da natureza e correspondente a criaçáo da vida. 
Este árbol está dividido en siete partes, a saber: raíces, tronco, ramas, ramos, hojas, flores, frutos; y cada uma de estas partes se divide en catorce partes, como la primeira parte, que es de las raíces del árbol elemental, vegetal, sensual, imaginal, humanal, moral, imperial, apostolocal, celestial, angelical, eviternal, maternal, cristianal, divinal; y lo mismo de la segunda parte y de los demás. Y cada uma de las siete partes está dividida en catorce partes para que podamos dar ejemplos de las naturas y maneras de los árboles según son sus raíces, troncos, ramas y las demas, y para que tengamos gran matéria para dar ejemplos, siendo asi que en los catorce árboles están todas as cosas explicadas e implicadas: y por los ejemplos que daremos puede el hombre tener doctrina para conocer los secretos natureles y sobrenaturales, y para predicar y para tener moralidades buenas y amistad de las gentes. Y más sún, que por ellos puede el hombre tener universal hábito para entender muchas cosas placenteras de entender y placenteras de ofr (LLULL, Ramon, 1981, p.519).

Para Llull, a árvore é o poder de explicar a própria existência, porque corresponde ao símbolo da vida e, os homens, ao compreenderem a natureza, deveriam ter o conhecimento dela desde a sua raiz até os seus frutos e folhas, pois ao relacionar a árvore com a criação e a vida, entenderiam que a natureza representa a necessidade de elementos essenciais para a sua própria sobrevivência. Logo, o homem também, para a sua sobrevivência e con/vivência como humano, precisa de elementos não só básicos, como também de valores que transcendem o simples sobreviver e se comprometem com a sociedade e seus respectivos valores humanos como a bondade; a benevolência; a benignidade; a generosidade, a sensibilidade dentre outras práticas virtuosas. Portanto, para Llull, é preciso ensinar o homem a ser uma pessoa humana e, por meio de suas obras, o autor revela a carência de sentimentos que persistia nas relaçóes sociais da sua época.

Quando analisamos obras como essa e compreendemos a mensagem que autores, como Llull, procuraram transmitir para a sua época, entendemos porque são considerados autores clássicos, haja vista que suas angústias e ensinamentos foram traduzidos por meios como a literatura, o conto, o canto, a novela, entre outras formas de ensinar aos homens valores predominantes para o seu período, mas que permanecem perenes na história.

Parafraseando Marc Bloch, caímos na afirmação de que conhecer 
o passado, na maioria das vezes, nos mostra como entender o presente e conseguir pensar que o homem é sempre homem, independentemente do período em que ele viveu, vive ou viverá. Desse modo, ao buscarmos clássicos de séculos passados vemos que a grande luta de conhecimento, travada por grandes autores, sempre cai e recai em sentimentos que revelam o homem como humano. Esclarecendo melhor, é dizer que, em momentos de mudanças, a tendência é de enfraquecimento dos valores e virtudes, que demonstram o ser humano fazendo uso do intelecto e fortalecendo a organização da sociedade. Por isso, a grande questão é a de mostrar à sociedade, por meio do conhecimento e de exemplos, que náo é impossível a prevalência de uma sociedade que náo está constituída por comportamentos humanos.

Assim, Llull, por exemplo, nos instiga a compreender qual o objetivo central das questóes que permeiam os debates realizados nas suas obras, pois ele cria um emaranhado de dúvidas que possibilitam os personagens a se contradizerem e, ao mesmo tempo, a se posicionarem valorizando sempre o conhecimento como principal eixo condutor da formação do homem.

Dessa forma, para melhor compreensão dos ensinamentos realizados pelo autor na obra O livro do Gentio e dos três Sábios, analisaremos (conforme imagem abaixo) algumas partes da obra Arbol Exemplificalis, na qual Llull detalha sobre a árvore e a sua representação como um dos maiores símbolos da criaçáo divina. Nesse sentido, para esse estudo, faremos uma breve análise sobre as raízes da árvore, pois ao entendermos as explicaçóes de Llull sobre as raízes, poderemos compreender o porquê das cinco árvores e da representação do espaço para o debate sobre a comprovaçáo da existência de Deus. Debate, este, realizado pelos personagens do gentio, dos três sábios e da inteligência. 


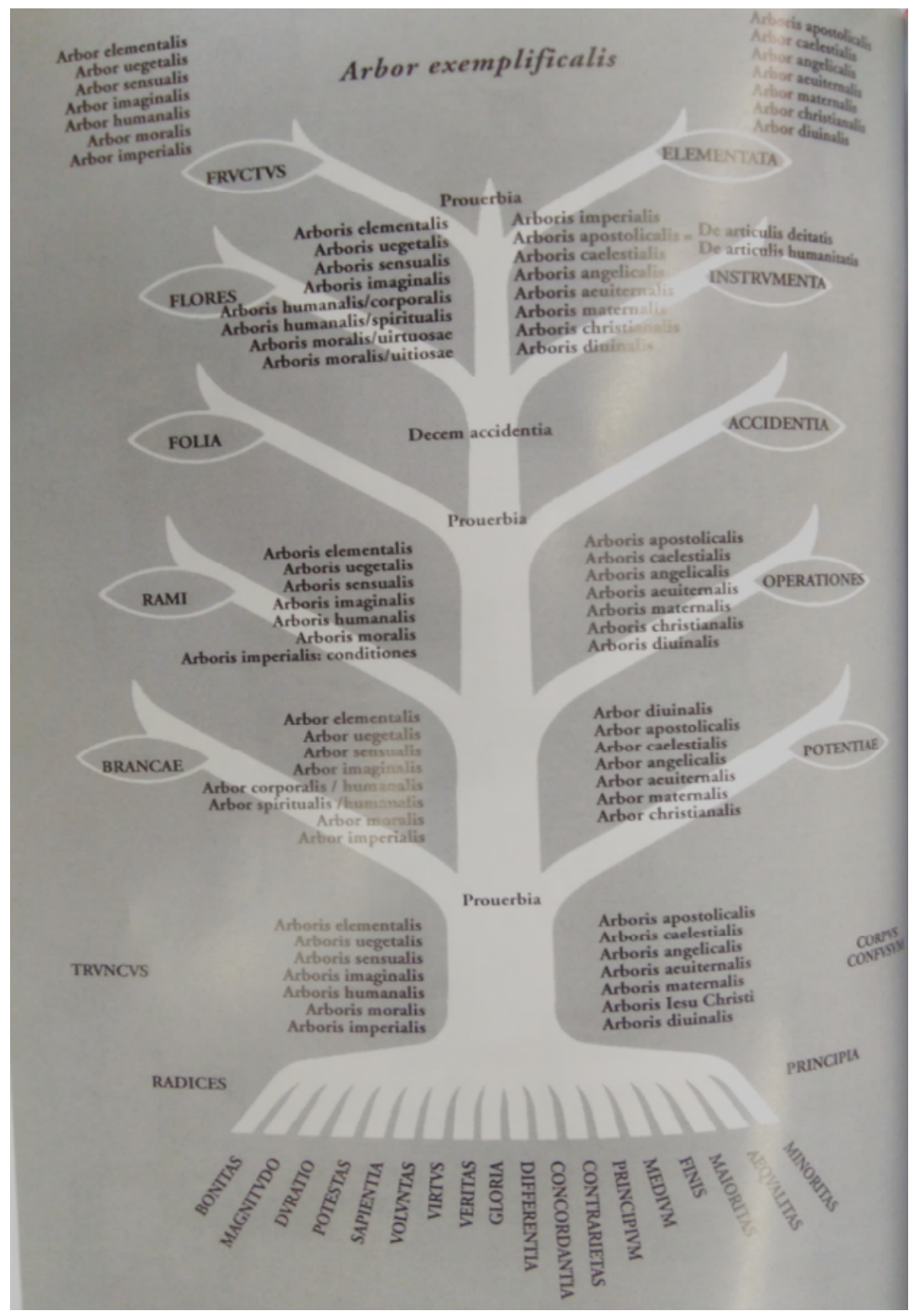

LLULI, Ramondi, (Imagem 1)3

3 Arbor Scientiae In: Corpvs Christianorvm: Continvatio Medievalis. Pere: Villalba Verneba. Volumen I. Libri I-VII. CLXXX $\Lambda$. TOMVS XXIV. BREPOL3. 
Observamos que a árvore tem dezoito raízes ${ }^{4}$ que correspondem ao lado direito e esquerdo do tronco: radices (raízes - lado direito) e principia (princípios - lado esquerdo). Ao fazermos uma relação entre a árvore e o homem (ambos criados por Deus), consideramos que Llull evidencia um dos lados com sentimentos inerentes ao homem e o outro com sentimentos possíveis de alterar o comportamento humano. Por exemplo, olhando a imagem da forma como está, do lado esquerdo vemos que o autor apresenta, da esquerda para a direita, a bondade; a grandeza; a duração; o poder; a sabedoria; a vontade; a virtude; a verdade e a glória. Continuando a sequência, da metade até o final do lado direito, temos a diferença; a concordância; a oposição; o médio; o final; a maioria; a igualdade e a minoria.

O lado esquerdo corresponde aos sentimentos inerentes ao homem em seu nascimento/sua 'gênese' e que devem, ou deveriam ser desenvolvidos, ao longo da vida, mas que, por conta do relacionamento do homem com seus semelhantes que não preservaram os sentimentos mais 'humanos', tendem a se perder, muitas vezes possibilitando que os maus sentimentos se tornem majoritários. Segundo Llull (de acordo com as raízes da árvore), isso é fácil de acontecer, já que, para ele, as diferenças são comuns e cada ser tem suas prioridades. Desse modo, a concordância por aquilo que é de melhor proveito se opóe a mediar e/ou ponderar as questóes, fazendo com que, no final, não prevaleça a igualdade entre os sentimentos, mas sim, a minoria de sentimentos que ordenam para o coletivo.

Llull usa dos quatro elementos da natureza: fogo; água; ar; terra, para explicar todas as partes da Árbol Exemplificais. Ele começa pelas raízes, apresentando os bons sentimentos contra os maus, exemplificados pelo fogo e pela água como principais protagonistas de disputa de poder, enquanto a terra e o ar são os que tentam amenizar e/ou entender os dois elementos.

[...] cuéntase que el aire yacía enfermo de dos enfermedades: una enfermedad tenia por amor y la otra por dolor. Enfermedad tenía por amor, porque estaba despegado de la tierra que tenía acción sobre el fuego, al cual él mucho amaba, y descaba que fuese señor de la tierra que era su enemiga; enfermedad de dolor tenía, porque sentía la sequedad que el fuego en él metía, cuya sequedad atormentaba su humedad. Y por esto dijo el agua al aire que

4 O número das raízes (dezoito) está em quase todas as representaçóes das árvores de Ramon Llull (Arbor Apostolicalis, Arbor Angelicalis, Arbor Maternalis, Arbor Diunilais, Arbor Caelestialis), entretanto, algumas das árvores não têm todas as raízes identificadas, ou seja, não estão nominadas, conforme a imagem acima da Arbor Exemplificalis. 
la recordase en su enfermedad, que tenía porque el fuego en él metía a su contrario, por razón de cuyo metimiento el aire debía desamar al fuego. Y esto decía el agua para que el aire fuese contrario al fuego y para que con ella tuviese concordancia. Mas respondió al agua y dijo que más amaba estar enfermo y ser buen amigo del fuego que la daba su semejanza que estar sano y cometer contra su amigo falta o engaño; porque ninguna enfermedad es tan grande como la enfermedad que es de traición y desconocimiento, que hace al hombre desconocer los beneficios que recibe de su señor. Y por eso dijo el aire que él quería ser sujeto y súbdito del fuego su señor, para que él tuviese acción en el agua en la cual se extendiese su señorío con grandeza de bondad y de virtud; porque gran virtud es para el calor del fuego y gran bien le es que sea dueño de su amigo por concordancia de amor, y de su enemigo por contrario señorío (LLULL, Ramon, 1981, p. 520).

$\mathrm{O}$ autor mostra a fidelidade de amizade do ar com o fogo, mesmo quando o fogo solta a sua secura e prejudica a umidade do ar. O fogo representa o poder de força e de imposição ao que ele quer para si, por isso o ar está sujeito aos desígnios do seu senhor e, mesmo sendo prejudicado, não abre mão da amizade entre eles.

Ocorre um debate entre o ar e a água, no qual Llull estabelece uma apresentação de bondade e de grandeza do ar pelo fogo, mostrando o poder que o fogo exerce sobre a terra, o ar e a água, além de expor as diferenças entre eles e a oposição que o ar sente pelo fogo. Ou seja, o ar se mostra doente de amor e, ao mesmo tempo, de dor pelo fogo, mostrando que, apesar dos dois sentimentos se contradizerem e demonstrarem confusão de prevalência, o ar opta por sentir a dor não como sentimento de traição ou de opressão, exercida pelo amigo sobre ele, mas sim, por culpa de sua fragilidade e dominação perante o fogo.

Nesse debate e com outros debates realizados na obra entre os quatro elementos, a nosso ver, existe uma explicação implícita sobre o domínio que o sentimento individual exerce sobre os homens, entendendo que, assim como o fogo, as vezes é mais fácil ou cômodo continuarmos sem ação do que assumir uma posição contrária ao que está posto e sofrer as consequências ou prejuízos que possa ocorrer nas pseudo amizades, relaçóes profissionais e familiares, dentre outras que permeiam o convívio interpessoal.

Nesse sentido, podemos fazer uma analogia entre a representação da árvore e do homem. A árvore, para Llull, simboliza o homem. As raízes correspondem aos diferentes sentimentos. Cada raiz representa um sentimento (bom ou mau) que nasce na terra (fertilizada ou não), sendo que juntas formam a árvore que dará 
bons ou maus frutos, ramas, flores etc., dependendo da terra em que nascem. $\mathrm{O}$ ser humano nasce na sociedade (terra) proliferada de bons e maus sentimentos e que interferem diretamente em sua formação, influenciando se terá bom ou mau caráter e que gerará filhos. Dessa forma, quando o autor insere os quatro elementos, ele mostra a dificuldade do homem em se posicionar para o bem coletivo, pois, primeiro, de acordo com a forma que foi educado, ele pensa nos próprios benefícios. Como exemplo, a conversa do ar com a água. $\mathrm{O}$ Ar apesar de poder ser mais amigo da Terra do que do Fogo, optou por ser fiel àquele que tinha maior domínio de poder, mesmo sendo desleal e prejudicando a todos, o Fogo. O Ar contou ao Fogo que,

Cuéntase que la Voluntad encontró a la Sabiduría mientras ella la Voluntad iba a una ciudad en donde estaba la Memoria, y a ella la Voluntad iba para que le recordase a su amigo. Y porque la Sabiduría llevaba consigo a Ira, que es enemiga de la Voluntad, la Voluntad no acogió bien a la Sabiduría, aunque le hubiese mostrado los caminos por los que podía encontrar a la Memoria; y cuando la Voluntad hubo ido a la Memoria que le recordó a su amigo, hicieron ambas gran fiesta y tuvieron gran solaz, tanto que la Sabiduría estuvo despagada contra la Voluntad, que no le había mostrado en su encuentro tan buen semblante como a la Memoria, de modo que la Sabiduría reprendió a la Voluntad ante la Memoria diciéndole que poco le agradecía los placeres que le había hecho. Excusóse la Voluntad, y dijo que mucho mayor placer sentía al dar su semejanza sin pasión que al tomar semejanza de otro con trabajo (LLULL, 1981, p. 523).

A passagem revela que a vontade individual, ao tomar suas decisóes, ora está direcionada pela sabedoria e pela memória, ora está sem elas, visto que, a vontade e a sabedoria dependem da memória para se entenderem e conciliarem as suas decisôes. De acordo com o autor "Disse a memória: sou substância criada, unida, à qual compete propriamente recordar e por acidente esquecer" (LÚliO, 2001, p. 175).

Novamente disse a Memória: sou composta dos meus princípios inatos, a saber: da bondade, da grandeza, etc., e essa é a primeira composição. A segunda composição é que sou substância composta da forma e da matéria. A terceira composiçáo é que sou composta com o intelecto e a vontade, porque todos os três somos uma só alma do homem. Mas, morto o homem, permanecemos isto que 
somos, porque permanecem as três espécies de composição antes nomeadas. Ao que segue que a própria alma é imortal, visto que tem por si e por sua natureza essas três espécies de composição (LÚLIO, 2001, p. 175).

A clareza com que Llull estabelece a relação entre o homem, a sabedoria, a vontade e a memória, nos possibilita elucidar a importância da leitura dos clássicos medievais independentemente do período tratado, pois em seus debates, na maioria das vezes, autores como Llull, nos direcionam a uma aproximação com as relaçóes humanas presentes na atualidade. Vejamos: hoje (início do século XXI), estamos sempre nos remetendo a falta de memória que a sociedade tem e que essa ausência de memória favorece alguns 'tipos' de sentimentos e comportamentos inexplicáveis nas relaçóes humanas, como exemplo: a corrupção; a vingança; o ódio; a falta de solidariedade, honestidade etc. Ou esclarecendo de outra forma, podemos dizer que o homem 'sem memória' se comporta pela vontade, sem sabedoria, posto que a sabedoria e a memória caminham juntas e, quando vinculadas, normalmente, a vontade é para o bem comum, conforme Llull expóe na passagem acima, onde clama as três composiçóes (vontade, sabedoria e memória).

Segundo o autor, quando a vontade e a sabedoria encontraram a memória e as três se uniram, o posicionamento da vontade mudou, ou seja, a distância entre a vontade e a sabedoria deixou de existir, revelando que o mau comportamento, realizado pela vontade do homem, era devido ao esquecimento sobre o bem comum, isto é, a vontade contrariou a sabedoria e se comportou de acordo com as atitudes que enalteciam o seu ego. Por isso, diz a memória:

Também pode ser provado pela Vontade, nossa irmã, que está no meio, escolhendo espécies novas pelo intelecto, e espécies antigas por mim. Se, no entanto, não fôssemos potências distintas, o intelecto e eu, a vontade no mesmo instante optaria por espécies novas e antigas e perder-se-ia a sucessão; o que é impossível. E, por esse motivo, como isso é assim, dizem mal aqueles que asseveram que eu e o intelecto somos a mesma potência (LÚLIO, 2001, p. 176).

A memória é a mediação entre a sabedoria e a vontade, pois se o homem usar a sabedoria e relacioná-la com a memória, a sua vontade será a ação relacionada e estabelecida pela lembrança. Desse modo, memória e intelecto são essenciais para a transformação do pensamento em ato.

[...] se esqueço o nome de algum homem, e o intelecto e a vontade requeressem que eu lhes devolvesse esse nome, que colocaram em mim, se me lembrasse de algumas operaçôes 
que esse homem fez bem ou mal ou com amizade ou com inimizade e lembrasse o fim, pelo qual o intelecto e a vontade apetecem que restitua aquele nome de homem, então pela minha bondade, grandeza, etc., sou coadjuvada para devolver a própria espécie, lembrando o próprio bom ou mau que segue; e assim da grandeza ou da pequenez etc., e, por isso, por tal disposição raramente acontecerá que eu náo devolva aquele nome do qual me esquecera (LÚLIO, 2001, p. 177).

Ao analisar alguns sentimentos que envolvem a ação do homem na participação e re/organização da sociedade, entendemos que a árvore (símbolo usado por Llull em várias de suas obras) representa a maneira que o autor usou para mostrar aos leitores e ouvintes a interligação da criação da natureza com a criação do homem e a relação de um com outro. Para tanto, Llull mostra também a importância de Deus como criador de tudo e a necessidade da crença de sua existência.

É nesse sentido que a obra O livro do Gentio e dos três Sábios (1274-1276) nos apresenta o debate criado pelo autor sobre as diferenças religiosas e a necessidade de entendê-las por meio de um só Deus, para não cair na mistura de sentimentos (representados pelas raízes) e no esquecimento do que é bom ou do que é mau. Ao entendermos a representaçáo realizada por meio das cinco árvores e das flores que cada uma delas contém, compreendemos as várias maneiras que Llull considerou como necessárias para levar os três homens religiosos e o descrente a debaterem sobre a importância do significado de cada flor, mediante a interpretação dada pela inteligência.

Outrossim, falar do passado (século XIII), compreendendo que a religião era o pré-requisito para tentar provar ao homem que, para ser humano, no sentido de humanidade, requeria-se muito mais do que falar e agir, é entender também, que as questóes humanas são sempre humanas, em qualquer época. Por isso, o nosso propósito, com esse trabalho, é analisar a forma que Llull tratou dos sentimentos e dos vícios e refletir que todos os sentimentos e vícios tratados na obra do século XIII, permanecem ainda hoje, século XXI, sendo debatidos e questionados pelo uso das suas práticas sem o devido conhecimento que possibilita discerni-los hierarquicamente para o bem comum.

\section{As árvores, os números, os sentimentos e os provérbios}

Das cinco árvores tratadas na obra, duas têm vinte e uma flores, a primeira e a quarta, as outras três trazem quarenta e nove flores. Se analisarmos o número total de flores de cada árvore, entendemos que são ímpares e que têm correspondência com o número sete (número este, considerado na Bíblia como número da perfeição). Ao verificarmos os provérbios relacionados com as flores, percebemos 
que nas três primeiras árvores, o autor destaca sete provérbios determinantes. $\mathrm{Na}$ primeira árvore são: bondade; grandeza; eternidade, poder, sabedoria, amor e perfeição. $\mathrm{Na}$ segunda árvore prevalecem: fé, esperança, caridade, justiça, prudência, fortaleza e temperança. $\mathrm{Na}$ terceira o autor apresenta os sete pecados capitais: gula, luxúria, avareza, acídia, soberba, inveja e ira. Desse modo, temos três grupos que contém sete provérbios para cada uma das três árvores. $\mathrm{Na}$ quarta e quinta árvores, Llull faz uma junção dos provérbios bons com os ruins, explicando a necessidade de existirem e se contradizerem na formação humana.

Partindo desse entendimento, recorremos à Bíblia, a fim de relacionar os ensinamentos do autor com os ensinamentos sagrados. Portanto, indiferentemente de ser o cristão que estava dando sua explicação, o judeu ou o muçulmano, compreendemos que os valores são considerados iguais. Por Llull, a interpretação pode ser diferente, mas o resultado final é ser o mesmo, ou seja, ensinar o homem a desenvolver os bons sentimentos para a sua formação.

Analisamos e comparamos alguns dos grupos com os ensinamentos bíblicos verificando a preocupação de Llull com a convivência social, a união entre os povos e a explicação de Deus perante a todos, sem a interpretaçáo singular de cada cultura e religiáo. A simbologia dos números náo está apresentada de forma explícita na obra, na verdade ela está nas entrelinhas das discussões realizadas pelo autor. Llull trata dos valores humanos e em cada grupo representado pelas flores, a repetição e a junçáo dos provérbios estáo relacionados com os números que simbolizam as explicaçóes divinas.

O sete, quando interpretado pelos ensinamentos sagrados, pode ser entendido, dentre as inúmeras vezes citado na Bíblia, como: o dia do descanso (após Deus ter feito o mundo em seis dias), o número da perfeição e da verdade. Acreditamos que Llull se pautou nos ensinamentos bíblicos que, normalmente, divide os períodos em sete, como exemplo em Levítico (23-25) que trata do sétimo dia da semana, das sete semanas que antecedem a Páscoa, o sétimo ano santo, o ano do jubileu que é contado "Contarás sete semanas de anos, sete vezes sete anos, isto é, o tempo de sete semanas de anos, quarenta e nove anos" (25: 8).

Desse modo, a divisão de Llull, ao tratar dos provérbios por meio dos grupos, também visualiza uma separação que pode manter a simbologia do número sete por meio de pecados e de virtudes. Nesse caso, ao agrupar as flores, o autor estabelece uma relaçáo entre os sentimentos e os comportamentos humanos:

Primeira árvore - Sobre a primeira árvore: bondade; grandeza; eternidade, poder, sabedoria, amor, perfeição

Partindo da explicação correspondente a cada árvore e realizada pela personagem da mulher nominada Inteligência, Llull inicia a primeira árvore sobre as sete virtudes, representadas por vinte e uma flores, separadas em pares. $\mathrm{O}$ primeiro par representa a bondade e a grandeza. Percebemos que o autor ensina 
aos homens que a bondade e a grandeza são essenciais ao ser humano e que o bem deve sobressair ao mal, por isso as duas coisas são necessárias e extremamente importantes para o homem conseguir discernimento das questóes que envolvem o todo. Logo, o oposto do homem bom e grande de sentimento é o homem mau e parvo, ou seja, mesquinho aos seus próprios sentimentos e com o pensamento na finitude de seus atos.

Percebemos que o bom coração de sentimentos é o início de toda explicação, com certeza, perante os três homens de diferentes crenças religiosas, a bondade é o que primazia o andamento das explicaçóes. Entendemos que Llull ensina aos homens da sua época, por meio da literatura, que ser bom e ter sentimentos de generosidade com os demais facilita a cada um justificar que o 'seu Deus' existe.

O segundo par é o da grandeza e da eternidade. Como a bondade e a grandeza são finitas, no sentido de que o bem realizado em vida, representado pelas ações humanas, finaliza quando o homem morre, logo, a eternidade é, sem dúvida, uma das melhores explicações e afirmaçóes para se crer em Deus. O criador, ao proporcionar a possibilidade do homem ser inteligente e poder usufruir da sua sabedoria para a descoberta de tudo, lhe proporciona também condiçóes de escolher a sua vida para o bem ou para o mal. Quando a escolha é feita para o bem comum, se torna perceptível que a formação do intelecto foi completa e que, desse modo, a crença para a vida eterna é resultado da certeza de que Deus existe.

Se náo existisse eternidade, conviria que tudo aquilo que existe tivesse começo; e se tudo aquilo que existe tivesse começo, seguir-se-ia que o começo seria começo para si mesmo. E assim, bons amigos, disse o sábio ao gentio, vós vedes que a razáo não admite isso, porque tudo aquilo que tem começo convém que tenha começo de alguma coisa que não tenha começo nem fim, e esta coisa é Deus da glória (LÚLIO, 2001, p. 52).

O debate sobre a importância da eternidade para a crença e o fortalecimento da fé como predominante à razão cria uma ligação da eternidade com o poder, ao qual Llull apresenta como terceiro par para a explicação.

O poder a que se refere, é o poder de Deus que o faz eterno, sem começo e sem fim. Logo, para Llull a 'eternidade e o poder concordam com o ser', pois para ser eterno é preciso ter o poder da criação e essa força só é entendida quando o conhecimento perpassa a razão e vai além do que se conhece empiricamente, ou seja, quando há compreensão de que por meio da razão se compreende o que é criado, mas não se explica, em tudo, a verdadeira forma da criação.

O quarto par é o do poder e da sabedoria. Este apresenta algumas definiçóes sobre a questáo da sabedoria quanto ao entendimento das coisas e para a 
interpretação das próprias virtudes. Llull deixa claro que a ignorância prevalece no não-ser ${ }^{5}$, sendo que a sabedoria e o poder, juntos, estáo ou deveriam estar no ser e que um sem o outro não estabelecem um conhecimento que possa gerar outras virtudes.

Por isso, se a carência de poder e a ignorância estáo no ser, apesar de convirem ao não-ser, quanto mais conviria que o poder e a sabedoria tivessem ser em alguma coisa na qual não houvesse carência de poder nem houvesse ignorância! E esta coisa é Deus, porque em todas as demais coisas há carência de pleno poder e de plena sabedoria (LÚLIO, 2001, p. 54).

A sabedoria permeia todo o debate realizado pelo Gentio e os três Sábios, visto que a própria 'zeladora' das árvores se apresenta como a Inteligência, desse modo percebemos que o conhecimento obtido por meio do desenvolvimento do intelecto, quando transformado em sabedoria, isto é, quando o homem age com bom senso, utilizando os sentimentos virtuosos para o bem comum, é o que Llull denomina, indiretamente, de sabedoria do ser.

Dessa forma, o grupo seguinte é o da sabedoria e do amor. A sabedoria é a que possibilita por meio do amor a boa ou má escolha, pois quando a sabedoria e o amor caminham juntos, o amor é atribuído àquele que merece recebê-lo pela bondade e pelos bons sentimentos. Vinculado a esse par está o par do amor e da perfeição. Para Llull, a perfeição é algo que só o amor pode conseguir e, se o verdadeiro amor está ligado a sabedoria, a perfeição é algo que também depende do conhecimento. Para o autor, a perfeição se revela em comportamentos, compreendendo que a boa conduta é aquela que se baseia nos ensinamentos de Deus e busca nesta relação a não existência da carência e sim da bondade, da grandeza, da eternidade, do poder e da sabedoria. E são esses pares que finalizam a primeira árvore: a bondade e a eternidade; a grandeza e o poder; a eternidade e a sabedoria; o poder e o amor.

Vemos que os três últimos pares que compõem a explicação das flores da primeira árvore se resumem a justificar e complementar cada um dos pares já explicados, isto é, cada sentimento se liga ao próximo, mostrando que nada está desligado do outro e que juntos formam o homem. Porém, devemos nos ater a questão de que Llull inicia com a bondade e finaliza com amor, mostrando que

5 Estar no ser indica algo muito mais forte que um mero existir. O ser é aquela atividade que do mais íntimo de cada coisa póe esta coisa, com todas as perfeiçóes que nela se encontram, na realidade. (Nota de rodapé de Esteves Jaulent in: Lúlio, Raimundo. O livro do gentio e dos três sábios. Vozes: Petrópolis, RJ, 2001, p. 55). 
esses são os elos da boa conduta, mas que, entre eles, tem os sentimentos bons e ruins e que quando há a sabedoria, ela medeia todos eles.

Segunda árvore - sobre a segunda árvore: fé, esperança, caridade, justiça, prudência, fortaleza e temperança

Os grupos da segunda árvore são tratados pelo autor numa direta relação de sentimentos que interligam todos eles, mostrando que um depende do outro para a ação e, também, para apresentar a importância de existir o bom e o mau sentimento em uma disputa de hierarquia. Segundo Llull, essa contradiçáo de sentimentos revela o caráter do homem e a sabedoria que foi utilizada para a execução da sua ação.

O primeiro par é composto pela bondade e pela fé. Percebemos que a bondade, já apresentada na primeira árvore, está ligada com a fé descrita na segunda árvore, revelando que apesar de serem árvores distintas, uma está interligada à outra pelos sentimentos, ou seja, assim como os homens e a relação social, tudo depende das açóes humanas para o estabelecimento e fortalecimento entre eles e das conquistas que possibilitam a re/organização da sociedade.

Dessa forma, a bondade e a fé estão juntas, mas a fé é dúvida, pois o homem que vive só pela fé não consegue entender todas as coisas, visto que a comprovação daquilo que não se entende, não é possível de ser realizada pela abstração. Logo, se não há a comprovação empírica pela fé, pode ocorrer uma descrença, o que, de acordo com o autor, é uma coisa ruim. Assim, segundo Llull, a bondade deve estar sempre junto com a fé, pois o bom coração crê sem ter a necessidade de entender o que não se comprova pela abstração.

O segundo grupo é o da grandeza e da esperança. Esse é simples, em razão de que ligado ao primeiro quem tem a bondade, no segundo há esperança, que facilita ver Deus na sua grandeza de bondade e de "[...] poder, eternidade, sabedoria, amor, perfeição, misericórdia, justiça e outras [...]" (LÚLIO, 2001, p.61). Os próximos pares (terceiro e quarto): eternidade e caridade; poder e justiça, são os pares que vão mediar os sentimentos que serão tratados nos pares quinto, sexto e sétimo, compreendendo que todos eles estão ligados à eternidade que prevê a caridade, o poder e a justiça como valores que estáo no homem e que serão eternos, quando forem exercidos na terra, seguindo as leis divinas.

O quinto par é o da sabedoria e da prudência. Esse é tratado por Llull como par que exerce a função de regular os demais sentimentos, pois "A prudência é a liberdade do coração que sabe e quer escolher o bem e o mal, ou escolher o maior bem e evitar o maior mal [...] quanto mais convém haver conveniência entre a sabedoria e ser virtuoso [...]" (LÚLIO, 2001, p. 63). Sendo assim, ser prudente é ter a sabedoria como mediadora das ações, dado que a sabedoria corresponde ao comportamento que é realizado pelo uso da inteligência. Portanto, o entender a ação é a ter realizado reflexivamente, por isso, o entendimento disse. 
- Eu sou absolutamente poderoso e inteligente, e poderoso me entendo acima de todo o curso da natureza, porque nem o possível nem o impossível naturalmente em nada podem me impedir, de forma que sou de uma ordem e natureza superior. Em verdade, não posso agir com maldade, com falsidade, ou vício, porque sou a Bondade, a Virtude e a Verdade absoluta, e esmorecer a minha Bondade ou Verdade seria decair da minha natureza (LÚLIO, 2001, p. 90).

Compreendo que a sabedoria e a prudência chegam ao entendimento e que, este não é possível de ser superado, haja vista que ele usa da sabedoria para chegar aos outros bons sentimentos, os dois próximos grupos: amor e fortaleza; perfeição e temperança, são os que finalizam a realização do comportamento humano nessa árvore. $\mathrm{O}$ amor é sinônimo de fortaleza, porque, segundo Llull, o homem só se torna forte quando tem o amor e usa da temperança para medir a perfeição, compreendendo que a perfeição tem sua medida, pois nada é tão perfeito, com exceçâo de Deus, ao ponto de exigir a medida exata para cada sentimento. Segundo o autor, sempre existirão os dois: o do bem e o do mal, cabe entáo, ao homem, após desenvolver a sapiência, saber dosá-los para a sua ação, pensando no bem coletivo.

Terceira árvore - sobre a terceira árvore: bondade e gula; grandeza e luxúria; eternidade e avareza; poder e acídia; sabedoria e soberba; amor e inveja; perfeição e ira

Nessa árvore temos uma nova versão de grupos. $\mathrm{O}$ autor apresenta os sete pecados capitais misturando-os com as virtudes apresentadas na primeira e na segunda árvores com os sentimentos de 'pecados', denominados por Llull como vícios, que residem no homem e que o levam a agir de diferente forma: egoísta ou abnegativa.

Porém, conforme Llull apresenta as raízes da árvore, os sentimentos se misturam e, segundo ele, essa é uma necessidade do existir, entendendo que para Deus, o bem e o mal se contradizem e a comprovação da existência de Deus só será acreditada por meio das açóes que acordam com os ensinamentos divinos. Os vícios, segundo o autor, são sentimentos que servem para desvirtuar o homem quando não há o discernimento entre um e outro (bom e mau).

Analisamos que Llull não descarta os pecados que, muitas vezes, têm predomínio das açóes humanas. Percebemos que ele justifica cada um deles, contradizendo os sentimentos, como exemplo no primeiro par, no qual ele afirma que "[...] a bondade conserva o ser e a gula o corrompe [...]", e continua "Ora, se a bondade, que é a virtude, e a gula, que é o vício, convém ao ser humano, quanto mais convém que a bondade esteja em alguma coisa que não seja vício, nem possa ser vício" ((LÚLIO, 2001, p. 65). A bondade deve superar a gula ou, melhor explicando, o homem quando age pelo estômago não usa a racionalidade 
para a compreensão do que é bom, ou seja, o homem age pela vontade dos seus instintos, do corpo, e náo pela sabedoria.

Os próximos três pares: da grandeza e da luxúria; da eternidade e da avareza e do poder e da acídia também estão relacionados a esse mesmo exemplo de preocupação e predomínio do corpo sobre a mente. Tanto a luxúria, quanto a avareza e a acídia, se contrapóem às virtudes que revelam a via da prática (comportamento humano) por meio do conhecimento, em razão de que, os bons sentimentos, na maioria das vezes, são dominados pelos vícios, corrompendo as açóes voltadas para o bem comum.

$\mathrm{O}$ quinto par é sobre a sabedoria e a soberba. Este requer uma atenção mais detalhada, no sentido de que o autor apresenta bem a contradição entre os sentimentos individuais (soberba) e o coletivo (sabedoria). Segundo Llull, soberba é sinônimo de ignorância, pois o homem orgulhoso, quanto mais se impóe pelo seu 'falso poder e/ou conhecimento', mais menosprezado é por aqueles que têm sabedoria. Ou seja, o homem ignorante engana aqueles que não têm o conhecimento suficiente para discernir o comportamento (a ação) do discurso, por isso que a partir do momento em que a ação realizada pela ignorância (pela individualidade) fica exposta e contraditória à 'falsa' comunicação realizada para o bem, “ [...] a sabedoria náo pode convir a alguma coisa onde haja possibilidade de ignorância, mas somente onde há perfeição de bondade, poder, amor [...]" (LÚLIO, 2001, p. 67).

Os dois últimos pares da terceira árvore correspondem ao amor e a inveja; a perfeição e a ira. Como já debatido anteriormente, os sentimentos entre o bem e o mal estão no homem, nas suas raízes e a prevalência de um ou outro resulta no desenvolvimento do conhecimento de cada um, portanto, amor, de acordo com Llull, é similar a justiça, enquanto a inveja é sinônimo de injúria e, ira e perfeição, sétimo par, são adversas, haja vista que a perfeição caminha junto com a caridade, contradizendo a ira que possibilita a fúria, a inveja, o egoísmo e outros maus sentimentos. Desse modo, afirma o autor "Ora, como negar essas coisas é algo inconveniente, conforme as condiçôes das árvores, por isso manifesta-se a ressureição à inteligência humana” (LÚLIO, 2001, p. 68).

Quarta árvore - sobre a quarta árvore: fé e esperança; esperança e caridade; caridade e justiça; justiça e prudência; prudência e fortaleza; fortaleza e temperança

$\mathrm{Na}$ quarta árvore, Llull reafirma a ligação entre os sentimentos, relacionando os pares da seguinte forma: primeiro par fé e esperança; no segundo ele traz a esperança, do primeiro, com a caridade; no terceiro a caridade com a justiça; no quarto a justiça com a prudência; no quinto a prudência com a fortaleza; no sexto a fortaleza com a temperança. Ele vai transformando os dois sentimentos de cada par em um que leva a formação do próximo e assim sucessivamente. Após essa mistura de virtudes e de terem sido provadas como essenciais na formação do 
homem, ele pede que a comprovação da quinta árvore revele a existência de Deus "Tendo o sábio provado, pela quarta árvore, as coisas acima mencionadas, então disse o gentio ao outro sábio que provasse, pela quinta árvore, que Deus existe, e nele há bondade, grandeza e as outras virtudes" (LÚLIO, 2001, p. 73).

Quinta árvore: sobre a quinta árvore: fé e gula; esperança e luxúria; caridade e avareza; justiça e acídia (preguiça); prudência e orgulho (soberba); fortaleza e inveja; temperança e ira

A quinta e última árvore tem os pares divididos em sete virtudes unificadas com os sete pecados capitais. Assimilamos que o autor deixou essa árvore como última comprovação da existência de Deus, para provar que Deus não é questionável, pelo fato de que, se para o homem ser completo como ser humano, é necessário ele ter a inteligência e ter o discernimento entre o certo e o errado na sociedade e, também, se as açôes individuais intervêm diretamente no coletivo, logo, o uso da sabedoria é imprescindível para a re/organização social. Logo, Deus é a própria inteligência, pois somente por meio da inteligência (que se torna sabedoria com o desenvolvimento do intelecto) é que se pode provar a existência dele. Por isso, Llull apresenta esse debate entre as diferentes religióes, provando que não é a religião que comprova que Deus existe ou não, mas sim, o uso dele para conhecer, discernir o reto e o incorreto para o bem comum e fazer uso das virtudes, por meio dos seus comportamentos e atitudes.

[...] fica manifesto que se o orgulho e a imprudência, a prudência e a humildade se encontram num mesmo sujeito, tanto mais, sem qualquer comparação, convém, necessariamente que haja alguma coisa na qual tenham ser a sabedoria e a humildade, sem que nela possam existir a imprudência nem o orgulho! E esta coisa é Deus. E se isso náo fosse assim, seguir-se-ia que a pedra e os corpos inanimados, ou dotados de alma irracional, conviriam à maior nobreza e melhor ao ser que o homem, enquanto que o ser humano não conviria a um ser que tivesse possibilidade de ter virtudes ou vícios. E como o homem é de mais nobre natureza que os inanimados ou irracionais, pelo fato de poder ser sujeito de virtudes, convém quem haja alguma essência mais nobre que o homem, que tenha virtudes e não possa estar submetido a vicíos, e esta é Deus, que nós buscamos (LÚLIO, 2001, p. 77-78).

Quando Llull explica cada árvore e justifica os sentimentos como flores, na verdade, ele relaciona a árvore como um todo, mas partindo das raízes, as quais vimos anteriormente, ou seja, as raízes saem da terra e essa terra pode ter uma mistura de terra boa e ruim, mas, quando cultivada e bem tratada ela consegue se fortalecer e desenvolver 
tronco, galhos, folhas, flores e frutos, que serão úteis para a natureza de um modo geral. Ao pensarmos na formaçáo do homem, quando ele é tolhido de conhecer e entender o quão é importante a sua conduta na sociedade, ele só fortalecerá o seu ego, poder, ganância, avareza, luxúria, dentre outros 'pecados capitais'. Llull ainda indica por meio da simbologia que, quando há o egoísmo e não o uso da sabedoria, o homem ensina o outro a ser igual a ele, pois, de uma forma ou outra, ele é um exemplo para os seus próximos, seja para os filhos, a esposa, os ouvintes, os amigos e outros.

Desse modo, o conhecimento, quando elevado ao nível da sapiência, em qualquer período, é o principal eixo da re/organização social, apreendemos que o nosso comportamento é sempre visto e analisado pelo outro e que, quando o outro não tem o conhecimento suficiente para discernir o que é o bem para o individual e, também, para o coletivo, vai tomar o comportamento como modelo para si (sendo bom ou mau exemplo).

Nesse sentido, de acordo com Llull "[...] onde há conveniência e ordem, é preciso que haja uma inteligência que as ordene, então eu serei a sua causa final, eficiente e ativa. Os iludidos pensam o contrário não sabe o que é a ordem" (LÚlIO, 2001, p. 89). A ordem corresponde a disciplina do entendimento que é a ação dos ensinamentos divinos, ou melhor, seguir os mandamentos de Deus. Ser ordenador de forma intrínseca e extrínseca:

[...] intrinsicamente, porque sou trino (inteligente, inteligível e entender); extrinsecamente, porque ordeno todas as coisas inteligíveis e naturais (as naturais, pelos seres inteligentes; as inteligíveis, por mim mesmo). Aqueles divergentes de mim, admitem um entendimento agente não-inteligente (porque não tem em si mesmo a intelecção) e um entendimento possível inteligente, e não sabem que na minha fecundidade há três supostos que neles mesmos subsistem. E, se suspeitam disso, partindo do entendimento humano, por número querem entender numeralmente a unidade, sendo assim que é preciso centrar-se na unidade, $\mathrm{e}$ da unidade passar ao número, numeralmente; pois entre o entendimento humano e mim, que sou simples e absoluto, há uma grande diferença e semelhança. Não admira, então, que, dispersos entre todas as coisas dispersas, deslizem em vários erros, servindo-se tortuosa e perversamente, e não certa e ordenadamente, de uma filosofia que lhes outorguei com finalidade ordenada e certa? (LÚLIO, 2001, p. 89).

A inteligência, que quase sempre é a protagonista das obras de Llull, na maioria das vezes, apresenta-se como a ordenadora das demais relaçóes de sentimentos. Percebemos que a inteligência ao se transformar em sapiência, direciona as 
boas ações humanas, mas que, para tal, é necessário que esta inteligência esteja fundamentada nos ensinamentos divinos, haja vista que, Deus deu ao ser humano o intelecto para ser desenvolvido e usado para discernimento da sua conduta.

$\mathrm{O}$ fato de o autor permear as suas obras com debates que procuram relacionar e transformar o conhecimento com a ação (teoria em prática), possibilita a nossa interpretação sobre a importância da formação do professor e da importância da relação do conhecimento e do ensino nos dias atuais.

\section{A importância do conhecimento e do ensino}

Podemos iniciar esse item com o seguinte questionamento: qual a relaçáo que podemos fazer entre um autor do século XIII-XIV e o século XXI? Se fizermos essa pergunta, mediante a desvalorização histórica e a falta de memória que presenciamos hoje no Brasil, responderíamos que 'nada'. Porém, se fizermos uma leitura analítica dos clássicos medievais, podemos compreender e responder essa questão de forma diferente. Afirmaremos que eles tratam sobre questóes humanas e/ou sobre prioridades da existência e sobrevivência do homem enquanto ser que pensa e age por meio da sua inteligência.

Logo, podemos continuar afirmando que estudar autores do passado nos dá a possibilidade de compreender melhor as relaçóes do presente e, também, nos permite entender que, muitas vezes, tanto no passado como no presente, a memória e a inteligência nem sempre estiveram ou estão relacionadas significativamente com a nossa conduta. Se refletirmos em alguns pontos que Llull analisou na sociedade da sua época, veremos que hoje ainda enfrentamos problemas parecidos, apesar dos vários séculos que nos separam e do desenvolvimento que ocorreu (em todas as instâncias), mas, em alguns aspectos, não podemos contar com muitos avanços, como exemplo, a falta de ligação entre memória, sabedoria e vontade que presenciamos nos dias atuais. Conforme apresentado, Llull mostra que a vontade, a sabedoria e a memória devem estar unificadas, a fim de que o resultado da ação seja para o bem coletivo e não para o individual, pois quando usamos somente a vontade e esquecemos a sabedoria e a memória, o mais provável é pensarmos primeiro no bem próprio e não no bem comum.

A prática, na sociedade atual, quando analisada de forma geral, está mais centrada nos interesses próprios e, na maioria das vezes, no resultado de más condutas que rapidamente são esquecidas pela maioria das pessoas. Porém, tais atitudes revelam o fato de que a memória e a sabedoria náo estáo ordenando a vontade. Outro ponto vinculado a este, e que podemos destacar, é a relevância que o autor nos remete sobre o conhecimento, quando correspondido ao sentido de inteligência, da sapiência. Apesar de Llull tratar cada item de boa e má conduta 
especificamente, na verdade, todos eles estão interligados e não se dissociam, conforme vimos acima simbolizados na relação das raízes com a formação da árvore. E, como não se dissociam, é preciso ter o conhecimento para discerni-los e saber como usá-los na prática. Desse modo, é o conhecimento que nos possibilita recordar os fatos, compreendendo que se o conhecimento faz a distinção entre o bem e o mal, ele recorda as más açóes, sem esquecê-las, ou seja, possibilitando o homem a não agir somente pela vontade.

Ao compreendermos melhor essas questóes, entendemos também que o papel de quem ensina é primordial para a formação do conhecimento, pois é o conhecimento que possibilitará ao cidadão realizar a ação pensando no bem comum, sabendo que a ação é realizada pela vontade e que normalmente se concretiza em uma boa conduta quando é refletida pela memória.

Nesse contexto, a nosso ver, o professor é um dos atores principais, pois é por meio do ensino formalizado, do conhecimento científico, que ele revela ao aluno o fato, as causas e as consequências nas diferentes áreas do conhecimento, possibilitando as condiçóes de desenvolvimento do intelecto. Portanto, é válido ressaltar que quando nos referimos ao professor e à responsabilidade profissional docente, estamos também discorrendo sobre a importância da formação do professor e do seu exemplo enquanto educador. A ação do mestre deve ser condizente com a sua teoria, esclarecendo melhor, quem ensina, ensina pela teoria e pela prática. Se o professor tem boa conduta fora da sala de aula, provavelmente conseguirá ensinar aos seus alunos a necessidade de aprender o conteúdo e saber relacioná-lo e praticá-lo no dia a dia.

Dessa forma, ser professor é ir além da sua realidade, do seu espaço presente, é conseguir compreender o seu papel e entendê-lo historicamente, saber que o conhecimento não está sendo exigido só na sua época, mas que sempre foi essencial na vida dos homens para o desenvolvimento individual e, consequentemente, social. Portanto, a leitura do passado por meio de autores clássicos e entendêlos no seu contexto, são essenciais para o discernimento do uso da razão na formação humana de qualquer época. Assim compreendemos que, "A história é busca, portanto escolha. Seu objeto não é o passado: «A própria noção segundo a qual o passado enquanto tal possa ser objeto de ciência é absurda.» Seu objeto é "o homem», ou melhor, "os homens», e mais precisamente "homens no tempo" (BLOCH, Marc, 2001, p.24).

Ainda segundo Bloch, "A ignorância do passado não se limita a prejudicar o conhecimento do presente, comprometendo, no presente, a própria ação" (p.24), ou seja, o desconhecimento histórico faz com que a compreensão fique ao alcance daquilo que é possível de ser entendido como questôes que só acontecem no presente, resultando na ação imediata, sem reflexão, ou como bem assevera Llull, ação realizada pela vontade, sem sabedoria e memória. 
Llull e autores como Hugo de São Vitor, São Boaventura de Bagnoregio, Nicolau de Cusa e outros, tiveram essas mesmas preocupaçóes com a formaçáo do homem. Cada qual se preocupou com determinadas questôes, porém todos tinham o mesmo objetivo, seja ele: ensinar ao homem da sua época que o conhecimento era o meio de o tornar humanizado, compreendendo que, ao ser mais educado, civilizado, seria um modelo de boa conduta e, consequentemente, contribuiria na organização da sociedade.

Portanto, analisando as preocupaçóes apresentadas por Llull, fica claro que os seus ensinamentos estavam centrados em um conhecimento que, embora ele considerasse necessário para a sociedade do final do século XIII e início do $\mathrm{XIV}$, via como essencial estabelecer a hierarquia de poder que os sentimentos e os vícios exerciam na vida dos homens, "E ainda disse o Entendimento. - Entre mim e a primeira Inteligência que vem depois de mim não existe diferença por contrariedade [...]" (LÚLIO, 2001, p. 89).

Nesse caso, o autor apresenta a inteligência como principal divulgadora dos sentimentos, revelando que é por meio dela que se tem a consciência do que é certo ou errado para a sociedade. Desse modo, os três religiosos, ao tentarem provar a existência de Deus por meio da comprovação da sua religião, fizeram com que Llull os colocassem em debate, criando uma situação de dúvidas e de questionamentos que só poderiam ser revelados pela inteligência.

A presença da inteligência como representante do conhecimento e cuidadora dos diferentes sentimentos que se apresentam em forma de flores, mostra a fragilidade que os homens podem ter ao se depararem com situaçóes que os fazem agir pela vontade e/ou sem o devido conhecimento para o discernimento das suas açóes. Assim, o debate entre as diferentes crenças e o fato de cada uma tentar provar por meio da fé a existência de Deus existe, a nosso ver, foi a forma de Llull mostrar aos homens da sua época que a comprovação de Deus não é realizada somente pela fé, mas sim, pelo conhecimento que se adquire pelo desenvolvimento do intelecto e que, usando a sabedoria, se comprova a existência de Deus por meio da Sua criação.

Por isso, Deus não existe porque é possível provar pela fé (abstração), mas sim pela comprovação (empírica) do que ele foi capaz de criar "Boa coisa é a fé, porque pela fé o homem crê e ama aquilo que o entendimento não pode entender; e se a fé não fosse nenhuma coisa, o homem não amaria, porque não a entenderia" (LLULL, Ramon, 2001, p. 60). Dessa forma, o autor nos direciona para o entendimento de que não é possível criar um debate sem ter o conhecimento suficiente para comprovar o que se fala. Era preciso ensinar os mandamentos divinos e agir conforme eles. As árvores, de acordo com a sua simbologia, representavam os diferentes sentimentos criados pelos homens e se misturavam, os bons e os ruins, mas quando o conhecimento buscava na memória as leis divinas, a ação refutava os sentimentos que priorizava somente o egoísmo. 
Ao ousarmos fazer uma analogia entre passado e presente, fica mais claro o comportamento existente na sociedade atual. A individualidade que ora pensamos ser de uma época tecnológica, não deve ser analisada de forma superficial, pois corresponde a sentimentos que sempre estiveram inerentes nos homens, independentemente da época, e que esses sentimentos, muitas vezes egoístas, acabam por aflorar mais em determinados períodos, talvez justamente pelo que vários autores do passado alertam, por falta de conhecimento suficiente para desenvolverem o intelecto e terem a consciência de usarem a inteligência vinculada com a memória.

\section{Referências}

BLOCH, M. Apologia da História ou o ofício do historiador, Introdução: GOFF, Le, Zahar, 2001.

COSTA, R. da. A experiência religiosa e mística de Ramon Llull: A infinidade e a Eternidade divinas no Livro da Contemplação (c. 1274). Scintilla - Revista de Filosofia e Mística Medieval, Curitiba. vol. 3, n. 1, p.107-133, jan./jun. 2006.

LEVÍTICIO. In: Biblía de Jerusalém. São Paulo: Paulus, 2006.

LÚlIO, R. O Livro do Gentio e dos Três Sábios (1274-1276). Tradução do Catalão. Intr. Trad. E notas de Esteve Jaulent. Petrópolis, RJ: Vozes, 2001.

LÚLIO, R. Escritos Antiverroístas (1309-1311). Trad. Brasília Bernadete Rosson, Sérgio Alcides, Ronal Polito. Porto Alegre, RS: EDIPUCRS, 2001.

LLULL, R. Árbol Exemplifical In: Obra Escogida; Vida Coetánea. Introducción: Miquel Batllori. Traducción y notas: Perer Gimferrer. Ediciones Alfaguara S.A. Madrid-ES, 1981.

LLULI, R. Arbor Scientiae In: Corpvs Christianorvm: Continvatio Medievalis. Pere: VillalbaVerneba. Volumen I. Libri I-VII. CLXXX $\Lambda$. TOMVS XXIV. BREPOL3.

RUIZ SIMON, J. M. A Arte de Raimundo Lúlio e a Teoria Escolástica da Ciência. Trad. Fernando Salles. São Paulo: Instituto Brasileiro de Filosofia e Ciência "Raimundo Lúlio", 2004.

Data de recebimento 08/07/2019.

Data de aceite 23/08/2020. 